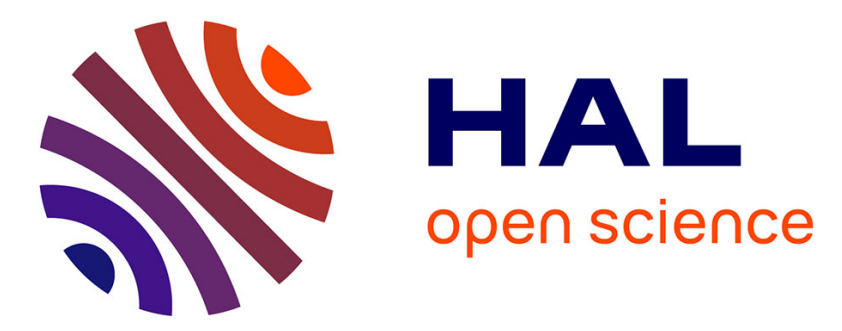

\title{
Electrodeposition, characterization and corrosion behaviour of tin-20 wt.\% zinc coatings electroplated from a non-cyanide alkaline bath
}

\author{
Sébastien Dubent, Marc L.A.D. Mertens, M. Saurat
}

\section{To cite this version:}

Sébastien Dubent, Marc L.A.D. Mertens, M. Saurat. Electrodeposition, characterization and corrosion behaviour of tin-20 wt.\% zinc coatings electroplated from a non-cyanide alkaline bath. Materials Chemistry and Physics, 2010, 120 (2-3), pp.371-380. 10.1016/j.matchemphys.2009.11.017 . hal02458179

\author{
HAL Id: hal-02458179 \\ https://hal.science/hal-02458179
}

Submitted on 28 Jan 2020

HAL is a multi-disciplinary open access archive for the deposit and dissemination of scientific research documents, whether they are published or not. The documents may come from teaching and research institutions in France or abroad, or from public or private research centers.
L'archive ouverte pluridisciplinaire HAL, est destinée au dépôt et à la diffusion de documents scientifiques de niveau recherche, publiés ou non, émanant des établissements d'enseignement et de recherche français ou étrangers, des laboratoires publics ou privés. 


\title{
Electrodeposition, characterization and corrosion behaviour of tin-20 wt.\% zinc coatings electroplated from a non-cyanide alkaline bath
}

\author{
S. Dubent ${ }^{a, *}$, M.L.A.D. Mertens ${ }^{b}$, M. Saurat ${ }^{a}$ \\ a Conservatoire National des Arts et Métiers, Chaire de Matériaux Industriels Métalliques et Céramiques, Case 321, 292 rue Saint-Martin, 75141 Paris Cedex 03, France \\ ${ }^{\mathrm{b}}$ Enthone B.V, RE'D, Postbus 1111, NL-5200 BD's Hertogenbosch, The Netherlands
}

Keywords:

Cadmium

Tin-zinc

Alloy coatings

Electrodeposition

Morphology

Spectrometry

Corrosion

Salt spray test

\begin{abstract}
A B S T R A C T
Tin-zinc alloy electroplated coatings are recognized as a potential alternative to toxic cadmium as corrosion resistant deposits because they combine the barrier protection of tin with the cathodic protection afforded by zinc. The coatings containing $20 \mathrm{wt}$.\% zinc, balance tin, offer excellent corrosion protection for steel and do not form gross voluminous white corrosion products like pure zinc or high zinc alloy deposits. In this study, the effects of variables of the process (i.e. cathodic current density, $\mathrm{pH}$ and temperature) on deposit composition have been evaluated using a Hull cell to obtain $20 \mathrm{wt}$ \% zinc alloy coatings. The tin-20 wt.\% zinc deposits, produced with electroplating optimized conditions, were characterized by scanning electron microscopy (SEM), energy dispersive X-ray spectrometry (EDS), X-ray fluorescence spectrometry (XRF) and glow discharge optical emission spectrometry (GDOES). On the other hand, the corrosion behaviour of tin-zinc alloy electroplated coatings on steel has been investigated using electrochemical methods in a $3 \mathrm{wt} . \% \mathrm{NaCl}$ solution and the salt spray test. The performance of the deposits was compared with cadmium and zinc-nickel electrodeposited coatings. The results show that the corrosion resistance of tin-20 wt.\% zinc alloy coating is superior to that of cadmium and zinc $-12 \mathrm{wt} . \%$ nickel coatings. Finally, sliding friction tests were conducted.
\end{abstract}

\section{Introduction}

It has always been of interest to the metal finishing industry to develop high-performance sacrificial electroplated coatings. Although pure zinc deposits continue to be used widely to supply protection to ferrous base metals, considerable efforts are being made to improve their corrosion resistance. When combined with nickel, iron, cobalt or tin, the coatings achieve performances that exceed that of zinc. Until the late 1970s, alloyed zinc electrodeposits have been suggested as superior sacrificial media. To date, $\mathrm{Zn}-12$ wt.\% Ni, Zn-06 wt.\% Fe and $\mathrm{Zn}-1$ wt.\% Co have received the widest attention and usage in industry. Tin-zinc coatings have several attractive properties: they provide good protection to a steel matrix, good frictional properties and wear resistance, and excellent solderability [1-3]. They are also ductile and have low electrical resistance. Because of such advantages, it is not surprising that a number of applications of tin-zinc alloy deposits were known and well recognized $[4,5]$. Tin-zinc coatings have been used on the chassis of electrical and electronic apparatus in the radio industry and

\footnotetext{
* Corresponding author. Tel.: +331 402726 57; fax: +331 40272341 . E-mail addresses: sebastien.dubent@cnam.fr, sebastienaucnam@yahoo.fr (S. Dubent).
}

on critical automotive parts such as fuel and brake components. At the time, tin-zinc was proposed as a substitute for cadmium coatings, which are toxic and carcinogenic [6-8].

Even though the patent filed by Marino in 1915 is probably the first known significant publication on tin-zinc coatings [9], the first extensive studies were carried out during the 1930s [10-14]. But it is only during the later stages of the Second World War that the deposition became a practicable process with the development of the stannate/cyanide tin-zinc plating electrolyte using polarized tin-zinc alloy anodes [15-17]. However, since the mid1960s the use of tin-zinc had declined considerably. This was likely due to the toxicity of cyanide baths and the difficulty to operate them [18-20]. Another probable reason was the cost disadvantage, because prior to 1985 tin was a relatively expensive metal and coded as a precious commodity. The "re-emergence" of tin-zinc coatings in the past decade can be attributed to the effort by several researchers to develop non-cyanide plating systems capable of producing bright deposits and the urgent problem of replacing cadmium coatings [21-26]. Several bath systems, using various complexing agents and additives, have been investigated. Previous studies have reported the influence of operating conditions on the properties of the coating, especially in its composition, which induced corrosion resistance $[2,20,24,27]$. In particular, it has been stated that the tin-20-30 wt.\% zinc alloy deposit has the most com- 
Table 1

Hull cell electroplating conditions for study of the influence on the tin-zinc alloy coating composition of current density (A), pH (B) and temperature (C).

\begin{tabular}{|c|c|c|c|}
\hline & A & B & $\mathrm{C}$ \\
\hline Tin metal $\left(\mathrm{g} \mathrm{L}^{-1}\right)$ & 51.5 & 58.8 & 60.5 \\
\hline Zinc metal $\left(\mathrm{g} \mathrm{L}^{-1}\right)$ & 6.51 & 7.23 & 7.53 \\
\hline $\mathrm{pH}$ & 10.0 & Variable & 10.1 \\
\hline Temperature $\left({ }^{\circ} \mathrm{C}\right)$ & 65 & 70 & Variable \\
\hline Period (min) & 15 & 15 & 15 \\
\hline Applied current intensity (A) & 1.0 & 1.0 & 1.0 \\
\hline Anodes & Sn/Zn 80-20 alloy & Sn/Zn 80-20 alloy & Sn/Zn 80-20 alloy \\
\hline
\end{tabular}

prehensive properties and provides the best corrosion resistance $[28,29]$.

In the present work, we first studied the effects of the electroplating conditions (i.e. cathodic current density, pHand temperature) of a non-cyanide alkaline bath on deposit composition to produce tin-20 wt.\% zinc alloy coating on a steel substrate. Then we characterized the deposits, obtained with electroplating optimized conditions, by scanning electron microscopy (SEM), energy dispersive X-ray spectrometry (EDS), X-ray fluorescence spectrometry (XRF) and glow discharge optical emission spectrometry (GDOES). Finally, we investigated the corrosion behaviour of the coatings using electrochemical methods in a $3 \mathrm{wt} . \% \mathrm{NaCl}$ solution and the salt spray test and compared the performance of the tin-20 wt.\% zinc alloy deposits with cadmium and zinc-nickel electrodeposited coatings.

\section{Experimental and methodology}

\subsection{Electrodeposition}

Tin-zinc coatings were deposited on low carbon steel plates of dimensions $70 \mathrm{~mm} \times 40 \mathrm{~mm}$. Before plating, the substrate was mechanically polished on silicon carbide abrasive paper ( 600 grit) then activated in a $10 \mathrm{wt} . \% \mathrm{HCl}$ solution and rinsed with distilled water.

The electroplating bath was a developed tin-zinc non-cyanide alkaline solution, supplied by Enthone France SAS (Cookson Electronics group) Zincrolyte ${ }^{\mathrm{TM}}$ Sn 0406. The full details of the bath formulation were not disclosed by the company.

The anodes used were suitably melted to have the same composition as the alloy coating, i.e. $20 \mathrm{wt} . \%$ zinc content, balance tin [30,31]. In order to ensure dissolution of tin in the stannic form $\left(\mathrm{Sn}^{4+}\right)$, the tin-zinc anodes were maintained in filmed conditions, as in the deposition of tin from an alkaline stannate bath. The film was established by slow insertion of the anodes into the solution with the current already flowing and after the cathode was already connected up in the bath and the plating circuit was complete [20].

\subsubsection{Electroplating conditions optimization-Hull cell}

Before deposits production, electroplating conditions were investigated using a Hull cell to obtain tin-20 wt.\% zinc alloy coatings. The vested interest of the Hull cell was to take advantage of the unique current density distribution. The Hull cell tests were carried out in a standard cell in order to evaluate the influence of current density, $\mathrm{pH}$ and temperature on the tin-zinc coating composition (Table 1). Low carbon steel plates with the dimensions of $70 \mathrm{~mm} \times 100 \mathrm{~mm}$ were used as Hull cell panel cathodes and a tin-20 wt.\% zinc anode was employed.

After electroplating, the zinc content in the alloy deposits and the thickness of the coatings were measured by XRF using a Fisherscope ${ }^{\circledR}$ X-Ray XUL Fischer spectrometer. The current density on the Hull cell panel was calculated using the following empirical formula:

\section{$j=I(4.28-4.20 \log l)$}

where $j$ is the current density on any point of the Hull cell panel, I the applied current intensity and $l$ the distance from any point of the panel to the highest current density end.

\subsubsection{Coatings accomplishment}

The electroplating conditions were optimized to produce tin-20 wt.\% zinc alloy coatings (Table 2). The deposits were carried out in a $2 \mathrm{~L}$ plating cell, made from a heat-resistant material and equipped with a thermostat. The volume of the bath was maintained at $1.5 \mathrm{~L}$ for all of the electrodeposition and the $\mathrm{pH}$ of the bath was monitored regularly by an electronic $\mathrm{pH}$-meter.
Table 2

Electroplating conditions to produce tin-20 wt.\% zinc alloy coatings.

\begin{tabular}{lll}
\hline & Batch 1 & Batch 2 \\
\hline Tin metal $\left(\mathrm{g} \mathrm{L}^{-1}\right)$ & $50.7-55.3$ & $52.7-54.1$ \\
Zinc metal $\left(\mathrm{g} \mathrm{L}^{-1}\right)$ & $6.76-7.42$ & $6.87-7.27$ \\
$\mathrm{pH}$ & $11.0-11.2$ & $11.0-11.2$ \\
Temperature $\left({ }^{\circ} \mathrm{C}\right)$ & 70 & 70 \\
Period $($ min $)$ & $45-50$ & 35 \\
Cathodic current density $\left(\mathrm{Adm}^{-2}\right)$ & 1.5 & 2.0 \\
Anodes & $\mathrm{Sn} / \mathrm{Zn} \mathrm{80-20} \mathrm{alloy}$ & $\mathrm{Sn} / \mathrm{Zn} 80-20$ alloy \\
Anodic current density $\left(\mathrm{A} \mathrm{dm}^{-2}\right)$ & 0.8 & 1.0 \\
\hline
\end{tabular}

\subsection{Characterizations}

After electrodeposition, the samples were characterized by scanning electron microscopy (SEM), energy dispersive X-ray spectrometry (EDS), X-ray fluorescence spectrometry (XRF) and glow discharge optical emission spectrometry (GDOES).

\subsubsection{Morphology-scanning electron microscopy}

The surface morphology of the tin-zinc electrodeposits was determined by SEM using a Cambridge Instruments Stereoscan S240 microscope.

\subsubsection{Composition homogeneity-energy dispersive X-ray spectrometry}

The tin-zinc alloy coatings were investigated by EDS at different surface locations to control the composition homogeneity of the deposits. All analyses were carried out with the same parameters: the electron beam was not modified, acquisition time (180 s) and dead time (25\%) remained unchanged.

\subsubsection{Global composition-X-ray fluorescence spectrometry}

After electrodeposition, each sample was analysed by XRF to determine the zinc content of the tin-zinc deposits and control process reproducibility.

\subsubsection{Depth composition-glow discharge optical emission spectrometry}

GDOES is a surface analytical technique, an atomic emission spectrometer system employing a non-thermal glow discharge source for atomic excitation [32] In a glow discharge, cathodic sputtering is used to remove material layer by layer from the sample surface. The atoms removed migrate into the plasma where they are excited through collisions with electrons or metastable carrier gas atoms. The characteristic spectrum emitted by these excited atoms is measured by the optical spectrometer [33].

The distribution of metal species in the tin-zinc layers was determined by depth profiling using a Horiba Jobin-Yvon JY $5000 \mathrm{RF}$ spectrometer equipped with a $4 \mathrm{~mm}$ diameter anode. The power to the plasma was supplied by a radio-frequency gen-

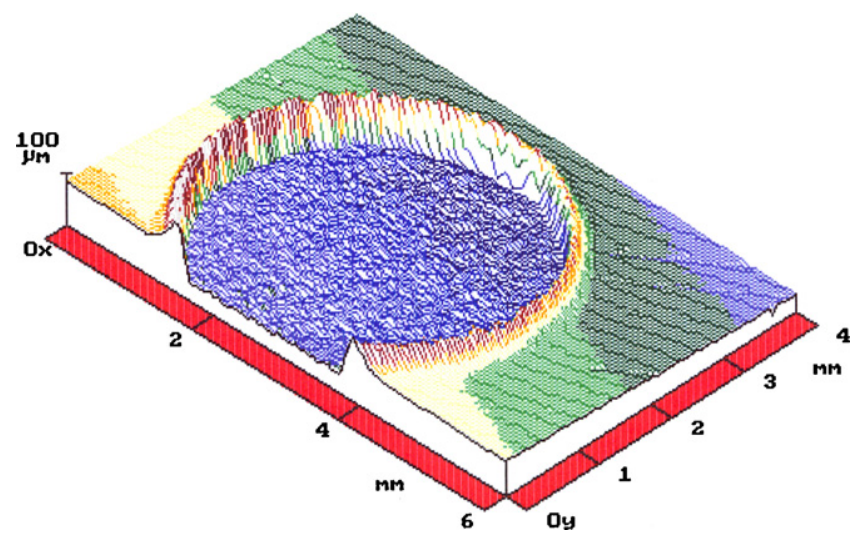

Fig. 1. GDOES crater profile in a tin-20 wt.\% zinc alloy coating. 


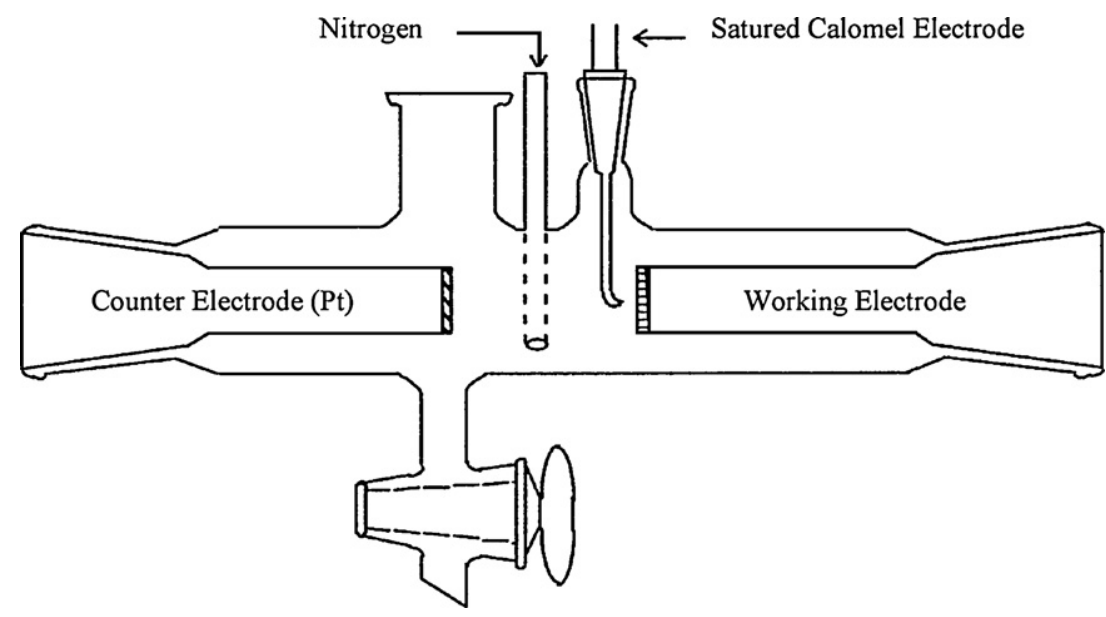

Fig. 2. Corrosion cell.

erator at a frequency of $13.56 \mathrm{MHz}$. A moderate power of $30 \mathrm{~W}$ was used for all analyses. High-purity argon was employed as the discharge gas, at a constant pressure of $400 \mathrm{~Pa}$. Quantified compositional results were evaluated automatically using Quantum IQ, the standard Jobin-Yvon software. The following atomic emission lines (Sn: $189.989 \mathrm{~nm}, \mathrm{Zn}: 481.053 \mathrm{~nm}, \mathrm{Fe}: 371.994 \mathrm{~nm}$ ) were calibrated with certified reference materials of known composition.

Depth profiles of the electrodeposited tin-20 wt.\% zinc alloys were performed by glow discharge optical emission spectrometry. Resolution degradation occurred with increasing depth caused by non-uniform sputter erosion resulting in a deformed crater shape [34]. To counteract this inherent feature and to obtain optimum interface resolution, different discharge parameters were studied. The crater shape sputtered with the chosen parameters is relatively clean: the crater bottom is sufficiently flat and, the bottom and the surface roughness similar (Fig. 1).

\subsection{Corrosion behaviour}

\subsubsection{Electrochemical measurements}

The open-circuit potential (OCP) and linear polarization resistance (LPR) measurements as well as the potentiodynamic polarization curves are generally used to characterize corrosion behaviour of alloys [24,35,36]. Since not long ago, the electrochemical impedance spectroscopy (EIS) has been widely recognized as a powerful method in studying electrode kinetics through means of the equivalent circuit models. This technique allows for the analysis of the electrochemical, electrical and mass-transport processes in the corrosion mechanisms of electrochemical reactions [37,38].

In view of the aforementioned, we investigated the corrosion behaviour of the tin-20 wt.\% zinc coatings produced and compared their performance with cadmium and zinc- 12 wt.\% nickel electrodeposited coatings using all of those electrochemical methods: i.e. OCP and LPR measurements, polarization curves to determine the corrosion currents $\left(i_{\text {corr }}\right)$ by Tafel slopes and EIS to decouple electrochemical, electrical and mass-transport impedances in the corrosion process by means of an equivalent circuit model.

All electrochemical measurements were performed at room temperature in a cell corrosion in a $3 \mathrm{wt}$ \% $\mathrm{NaCl}$ solution on nitrogen bubbling. A saturated calomel electrode (SCE) was used as the reference and a platinum sheet was employed as the counter electrode. The exposed surface of the working electrode was $1 \mathrm{~cm}^{2}$ (Fig. 2). A Radiometer Analytical PGZ 100 potentiostat under computer control was used as the electrochemical analyser system. The OCP and the LPR of various deposits were measured for about $10,000 \mathrm{~s}$ when they were immersed into the $\mathrm{NaCl}$ solution. The polarization curves were recorded in a potential range from -1.8 to $0 \mathrm{~V} / \mathrm{SCE}$ with a scanning rate of $1 \mathrm{mV} \mathrm{s}^{-1}$ and the corrosion currents were deduced from the Tafel slopes. On the other hand, impedance measurements were recorded at OCP with alternating current amplitude of $10 \mathrm{mV}$ in a frequency range from $100 \mathrm{kHz}$ to $0.01 \mathrm{~Hz}$. Impedance results were given in Nyquist representation.

\subsubsection{Salt spray test}

A salt spray test was performed under the criteria established by ASTM B117 to study and compare the corrosion behaviour of the tin-20 wt.\% zinc coatings produced with cadmium and zinc-12 wt.\% nickel electrodeposited coatings. The samples were controlled every $24 \mathrm{~h}$.

\subsection{Friction resistance-sliding friction tests}

Sliding friction tests were conducted to estimate and compare the friction coefficient of the tin-20wt.\% zinc coatings produced, of cadmium coatings and of zinc-12 wt.\% nickel electrodeposited coatings. The strength $(P)$, applied on the coated skate, was $500 \mathrm{~g}$ (Fig. 3). The rotation speed of the steel track was $500 \mathrm{rpm}$ The tests were stopped upon observation of a total jamming.

\section{Results and discussion}

\subsection{Influence of current density, $\mathrm{pH}$ and temperature on tin-zinc coatings composition}

Before deposits production, electroplating conditions were investigated using a Hull cell to evaluate their influence on the coatings composition and thus optimize current density, $\mathrm{pH}$ and temperature to obtain tin-20 wt.\% zinc alloy deposits.

As can be seen in Fig. 4, zinc content of the tin-zinc coating decreases with an increase in $\mathrm{pH}$ and, to a small degree, with an increase in the temperature of the plating bath (Fig. 5). However, zinc content of the deposit becomes constant for superior to 11 $\mathrm{pH}$ values. That effect is especially interesting as part of this study because the corresponding zinc content is thus included between 20 and 30 wt.\% (Fig. 4). Furthermore, the thickness of the tin-zinc coating increases with cathodic current density and with the temperature of the plating bath (Fig. 6). To the contrary, $\mathrm{pH}$ does not seem to affect the thickness of the deposit (Fig. 7).

In this study, we were mostly interested in tin-20-30 wt.\% zinc coatings because it has been stated that they have the most comprehensive properties and provide the best corrosion resistance $[28,29]$; so we applied 1.5 and $2 \mathrm{~A} \mathrm{dm}^{-2}$ as plating cathodic current

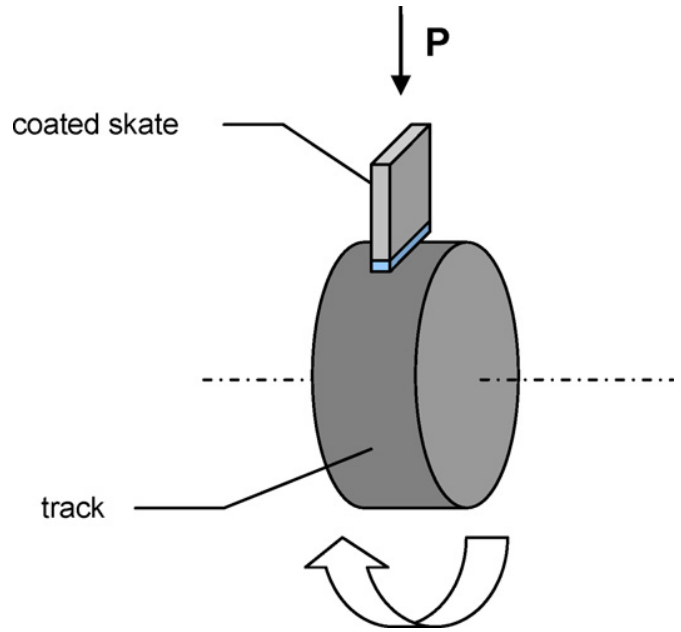

Fig. 3. Schematic principle of the sliding friction test. 


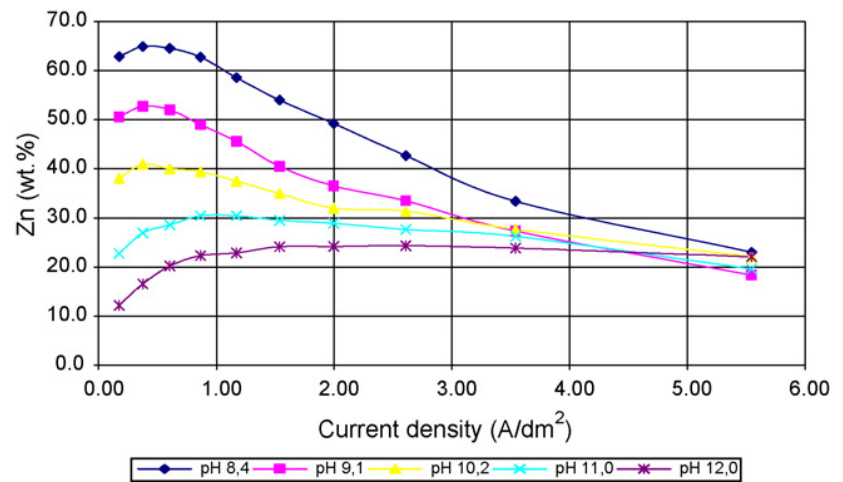

Fig. 4. Effect of $\mathrm{pH}$ of the plating bath (temperature $=70^{\circ} \mathrm{C},\left[\mathrm{Sn}^{4+}\right]=58.8 \mathrm{~g} \mathrm{~L}^{-1}$, $\left.\left[\mathrm{Zn}^{2+}\right]=7.23 \mathrm{~g} \mathrm{~L}^{-1}\right)$ at variable current density on the zinc content of the tin-zinc alloy coating.

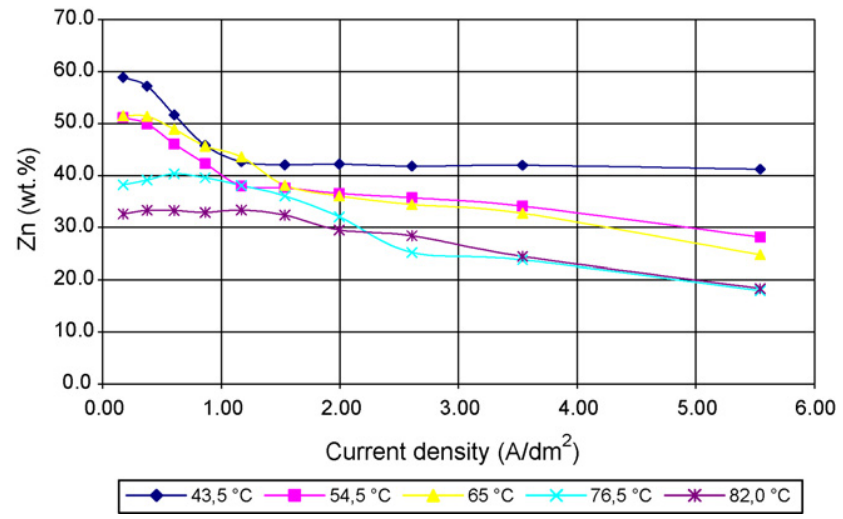

Fig. 5. Effect of the temperature of the plating bath $\left(\mathrm{pH} 10.1,\left[\mathrm{Sn}^{4+}\right]=60.5 \mathrm{~g} \mathrm{~L}^{-1}\right.$, $\left.\left[\mathrm{Zn}^{2+}\right]=7.53 \mathrm{~g} \mathrm{~L}^{-1}\right)$ at variable current density on the zinc content of the tin-zinc alloy coating.

density and respectively 11 as $\mathrm{pH}$ and $70^{\circ} \mathrm{C}$ as the temperature of the bath to produce tin-20 wt.\% zinc alloy electrodeposits (Table 2).

\subsection{Characterization of tin-20 wt.\% zinc alloy coatings}

SEM micrographs of various tin-zinc coatings carried out are presented in Fig. 8 under $1500 \times$ magnification. For each deposit, it is possible to observe two pictures corresponding to two different thicknesses from the layer. Indeed the electrolytic deposits are dependent on the distribution of the threads of current, which

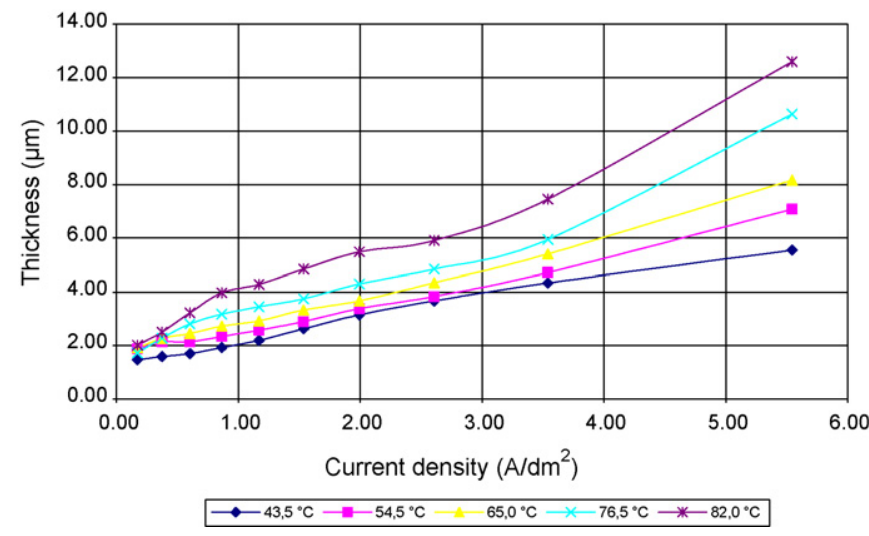

Fig. 6. Effect of the temperature of the plating bath ( $\mathrm{pH} \mathrm{10.1,}\left[\mathrm{Sn}^{4+}\right]=60.5 \mathrm{~g} \mathrm{~L}^{-1}$, $\left[\mathrm{Zn}^{2+}\right]=7.53 \mathrm{~g} \mathrm{~L}^{-1}$ ) at variable current density on the thickness of the tin-zinc alloy coating.

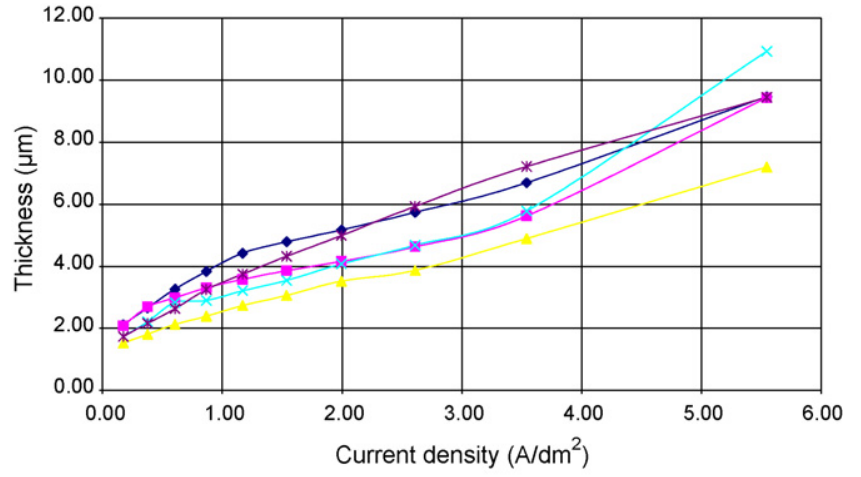

$-\circ \mathrm{pH} 8,4--\mathrm{pH} 9,1-\mathrm{pH} 10,2-x-\mathrm{pH} 11,0 \rightarrow *-\mathrm{pH} 12,0$

Fig. 7. Effect of $\mathrm{pH}$ of the plating bath (temperature $=70^{\circ} \mathrm{C},\left[\mathrm{Sn}^{4+}\right]=58.8 \mathrm{~g} \mathrm{~L}^{-1}$, $\left.\left[\mathrm{Zn}^{2+}\right]=7.23 \mathrm{~g} \mathrm{~L}^{-1}\right)$ at variable current density on the thickness of the tin-zinc alloy coating.

concentrate on the edges and in the angles of the cathode, a phenomenon commonly called "edge effects" in the field of surface treatments of metals. The thickness of tin-zinc coating is consequently more important in the angles than in the centre of the steel plate.

All deposits have the same relatively uniform morphology. They consist of nodules from approximately $4 \mu \mathrm{m}$ diameter. Moreover it is interesting to note that roughness increases with the thickness of the deposited layer.

The elaborated coatings were investigated by energy dispersive X-ray spectrometry (EDS) at different surface locations to control composition homogeneity. Fig. 9 shows a spectrum of one of the tin-20 wt.\% zinc deposits. It is important to note that the lines of tin and zinc are easily identifiable and especially quite separate, which means that their energy levels are very different and thus that the detector can dissociate tin from zinc perfectly. The results of analyses carried out on a diagonal on the surface of the deposits (Table 3) are consequently comparable for the same coating, on the condition of considering only the ratio of the net number of counts per second reported to the total number of counts per second for each element (the net number corresponding to the number of counts from which the spectral bottom was withdrawn and the total number corresponding to the number of counts for the whole spectrum).

According to the tin-zinc phase diagram, tin and zinc have very low mutual solubility. The tin-20 wt.\% zinc alloy would thus not form a single-phase compound at room temperature but would correspond to a hypereutectic two-phase compound with a solid $2.5 \mathrm{wt}$.\% zinc $\alpha$ phase and pure zinc.

In view of the results however (Table 3 ), the tin-zinc alloy deposit seems to form an intimate and homogeneous mixture. Until $3000 \times$ magnification, the EDS spot analysis cannot find any composition difference at different surface locations, indicating that the tin-20 wt.\% zinc coating, contrary to the same composition tin-zinc alloy elaborated by metallurgical way, forms a homogeneous compound. We can consequently think that the corrosion resistance of the electrolytic tin-zinc alloy deposit is superior to that of the same composition cast alloy.

To determine the zinc content of the tin-zinc alloy coatings and control process reproducibility, every elaborated sample was analysed by X-ray fluorescence spectrometry (XRF). The results indicate that the zinc content is included between 16.5 and $21.7 \mathrm{wt} . \%$, the average content being of $19.0 \mathrm{wt} . \%$ (Table 4). The realized experiments, in order to produce tin-20 wt.\% zinc coatings, are thus completely satisfactory. The composition of the deposits, which allows according to the bibliography for obtaining the best corrosion resistance and for which the parameters of electrolysis were 


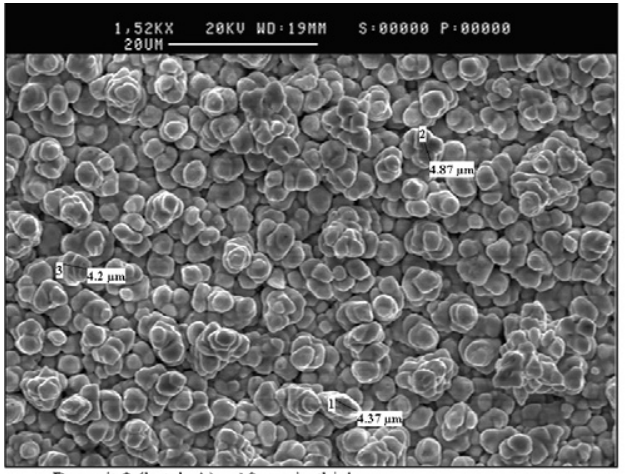

Deposit 2 (batch $A)-10 \mu \mathrm{m}$ in thickness

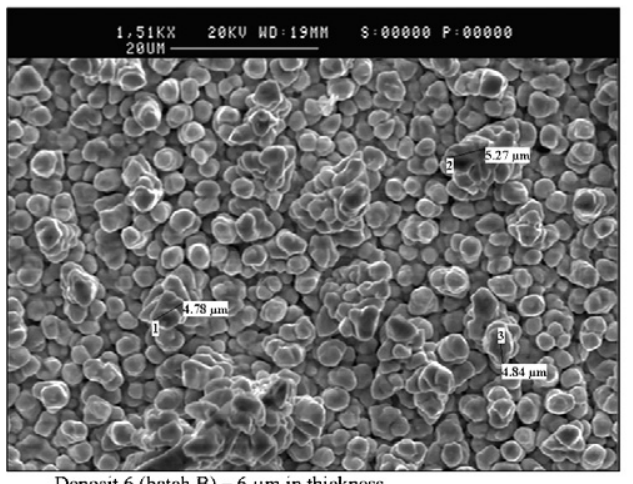

Deposit 6 (batch $B$ ) $-6 \mu \mathrm{m}$ in thickness

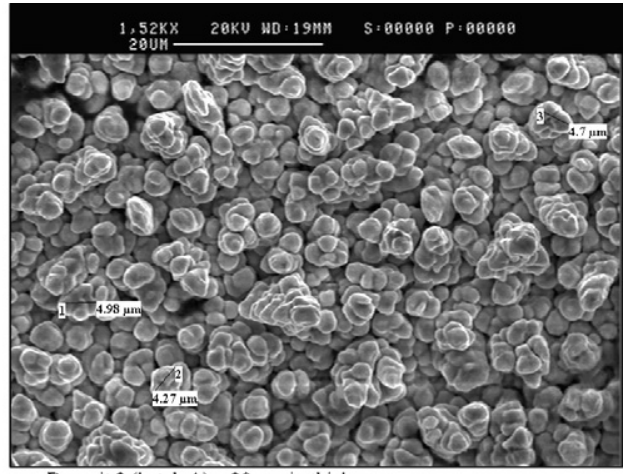

Deposit 2 (batch A) $-20 \mu \mathrm{m}$ in thickness

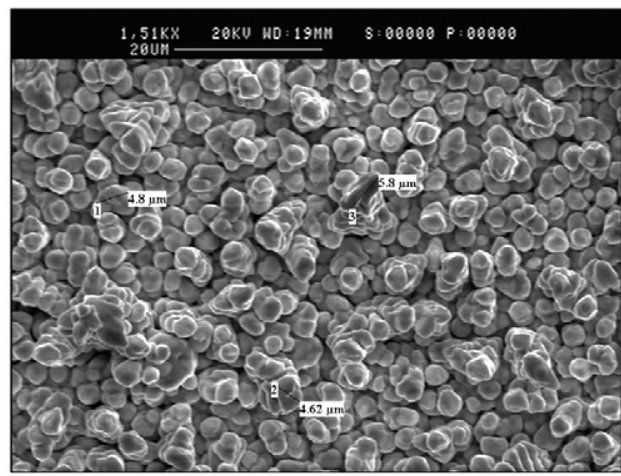

Deposit 6 (batch $\mathrm{B})-12 \mu \mathrm{m}$ in thickness

Fig. 8. SEM micrographs of two tin-20 wt.\% zinc alloy coatings.

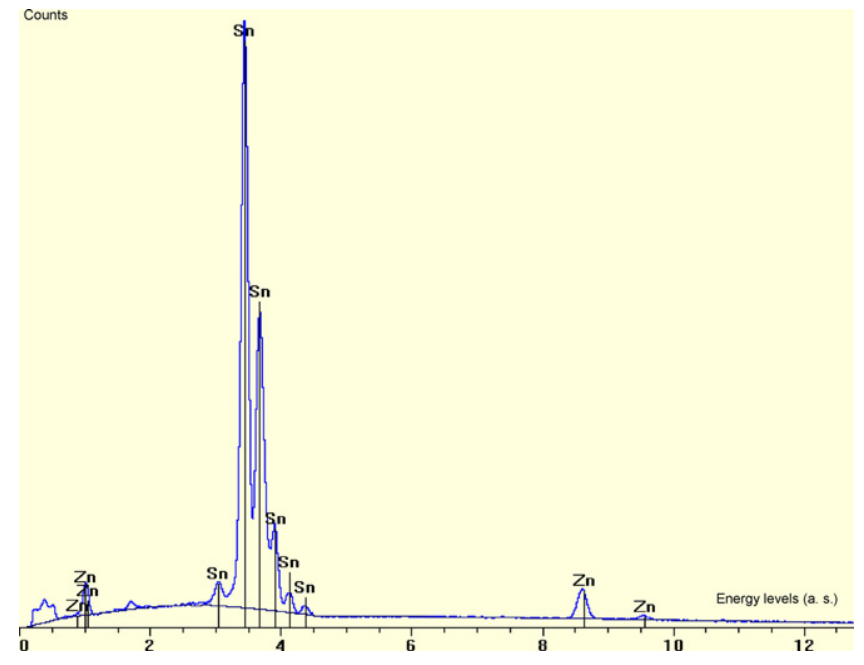

Fig. 9. Energy dispersive X-ray spectrum of a tin-20 wt.\% zinc alloy coating (magnification: $3000 \times$, acquisition time: 180 s, dead time: $25 \%$ ). optimized, was indeed reached. Moreover we demonstrated that the process is reproducible. The composition of each coating originally from each batch remains constant for identical operating conditions.

With regard to the thickness, the deposits carried out present rather important "edge effects" (Table 4).

At last, depth profiles analyses on the electrodeposited tin-zinc alloys were performed by glow discharge optical emission spectrometry (GDOES). Fig. 10 shows on the same graph qualitative and quantitative profiles of all the coatings. The composition of the whole of the tin-zinc deposits is reproducible and homogeneous; profiles are identical and zinc content, raised in m-deposit, is included between 17 and $21 \mathrm{wt} . \%$, which confirms the results obtained by XRF.

Nevertheless if the composition remains the same from one deposit to the other one, it does not seem homogeneous on all the thickness of the coating. Indeed Fig. 10b shows an increase in the zinc content with the sputtering depth, which means that the co-deposited zinc content decreased during the process of electrolysis. This phenomenon could be explained by a selective dissolution

Table 3

Results of the EDS analyses carried out on different surface locations of four tin-zinc deposits (magnification: $3000 \times$, acquisition time: 180 s, dead time: $25 \%$ )

\begin{tabular}{|c|c|c|c|c|c|c|c|c|}
\hline \multirow[t]{3}{*}{ Analysis } & \multicolumn{8}{|c|}{ Net number of counts/total number of counts ${ }^{\mathrm{a}}$} \\
\hline & \multicolumn{2}{|c|}{ Deposit A } & \multicolumn{2}{|c|}{ Deposit B } & \multicolumn{2}{|c|}{ Deposit C } & \multicolumn{2}{|c|}{ Deposit D } \\
\hline & Sn & $\mathrm{Zn}$ & Sn & $\mathrm{Zn}$ & Sn & $\mathrm{Zn}$ & Sn & $\mathrm{Zn}$ \\
\hline 1 & 0.179 & 0.018 & 0.174 & 0.021 & 0.194 & 0.007 & 0.193 & 0.050 \\
\hline 2 & 0.182 & 0.019 & 0.180 & 0.018 & 0.198 & 0.008 & 0.186 & 0.056 \\
\hline 3 & 0.177 & 0.019 & 0.184 & 0.018 & 0.197 & 0.006 & 0.191 & 0.046 \\
\hline 4 & 0.184 & 0.019 & 0.183 & 0.017 & 0.193 & 0.009 & 0.189 & 0.048 \\
\hline 5 & 0.187 & 0.017 & 0.182 & 0.016 & 0.195 & 0.010 & 0.195 & 0.054 \\
\hline SD & 0.004 & 0.001 & 0.004 & 0.002 & 0.002 & 0.001 & 0.003 & 0.004 \\
\hline
\end{tabular}

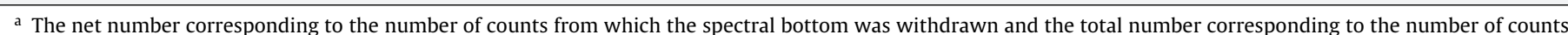
for the whole spectrum. 
Table 4

Results of the XRF analyses carried out on different surface locations of the elaborated deposits.

\begin{tabular}{|c|c|c|c|c|c|}
\hline \multirow[t]{2}{*}{ Batch } & \multirow[t]{2}{*}{ Deposit } & \multicolumn{2}{|l|}{ wt.\% } & \multicolumn{2}{|c|}{ Thickness ( $\mu \mathrm{m})$} \\
\hline & & Sn & $\mathrm{Zn}$ & Minimum & Maximum \\
\hline \multirow[t]{4}{*}{ A } & 1 & 79.2 & 20.8 & 8.3 & 12.4 \\
\hline & 2 & 78.3 & 21.7 & 10.7 & 20.4 \\
\hline & 3 & 80.5 & 19.5 & 10.0 & 17.6 \\
\hline & 4 & 80.1 & 19.9 & 7.2 & 14.1 \\
\hline \multirow[t]{5}{*}{ B } & 5 & 82.1 & 17.9 & 7.1 & 13.7 \\
\hline & 6 & 82.2 & 17.8 & 6.5 & 12.0 \\
\hline & 7 & 82.9 & 17.1 & 8.3 & 13.5 \\
\hline & 8 & 80.3 & 19.7 & 8.9 & 15.3 \\
\hline & 9 & 83.5 & 16.5 & 7.2 & 12.2 \\
\hline Average & & 81.0 & 19.0 & 8.3 & 14.6 \\
\hline SD & & 1.7 & 1.7 & 1.4 & 2.8 \\
\hline
\end{tabular}

of the tin-zinc alloy anodes: anodes tend to oxidize slightly during the electrolysis, limiting more the dissolution of zinc than tin in the bath, thus supporting the reduction of this last on steel plate.

However, knowing that in the alkaline solutions the reduction of tin and zinc is slowed down by the adsorption of hydrogen on the surface of steel, a second hypothesis is more likely. Overpotential corresponding to the reduction of hydrogen is weaker for steel than for zinc or tin. During the first seconds of electrolysis, zinc and tin are in competition with hydrogen on the surface of steel. Then, as soon as some atomic layers of tin-zinc are deposited on the surface of the substrate, the effect of steel on hydrogen decreases; it decreases more especially as the thickness of the coating increases. This phenomenon, helped by the exchange reaction between zinc and $\operatorname{tin}\left(\mathrm{Zn}+\mathrm{Sn}^{2+} \rightarrow \mathrm{Zn}^{2+}+\mathrm{Sn}\right)$, could thus be the cause of the more
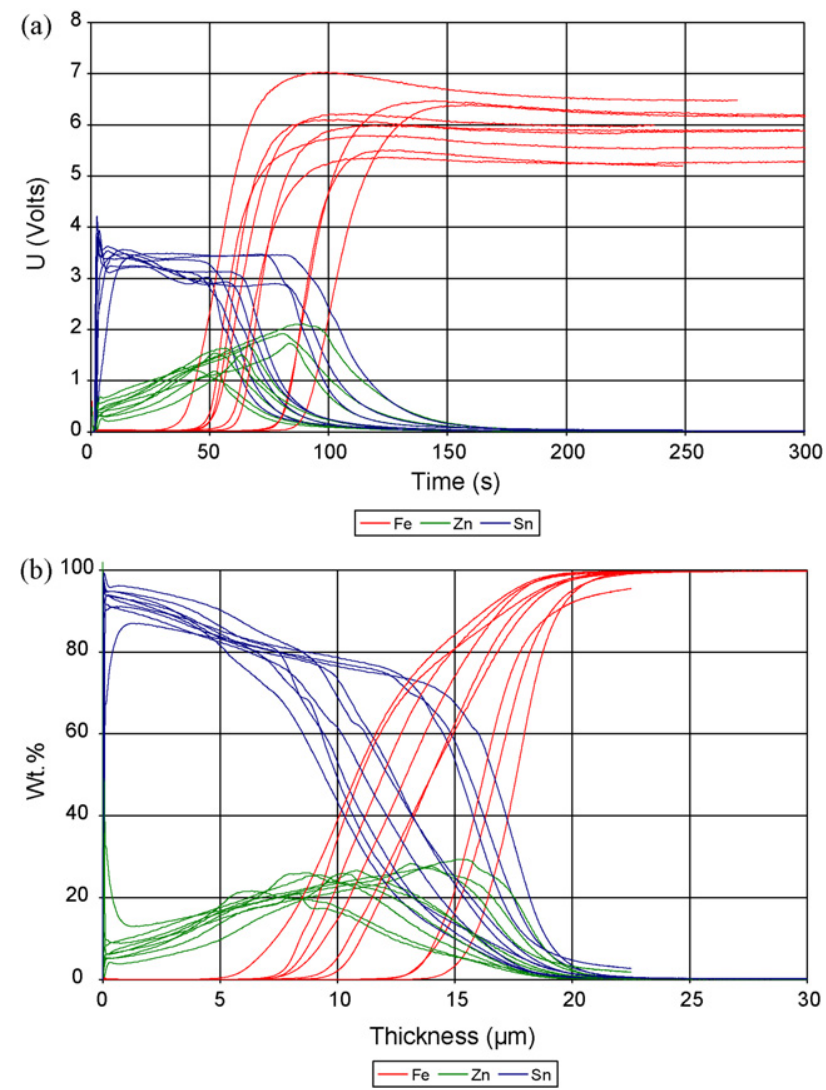

Fig. 10. Qualitative (a) and quantitative (b) depth profiles of all the tin-zinc alloy coatings electrodeposited on steel substrates (batches A and B).

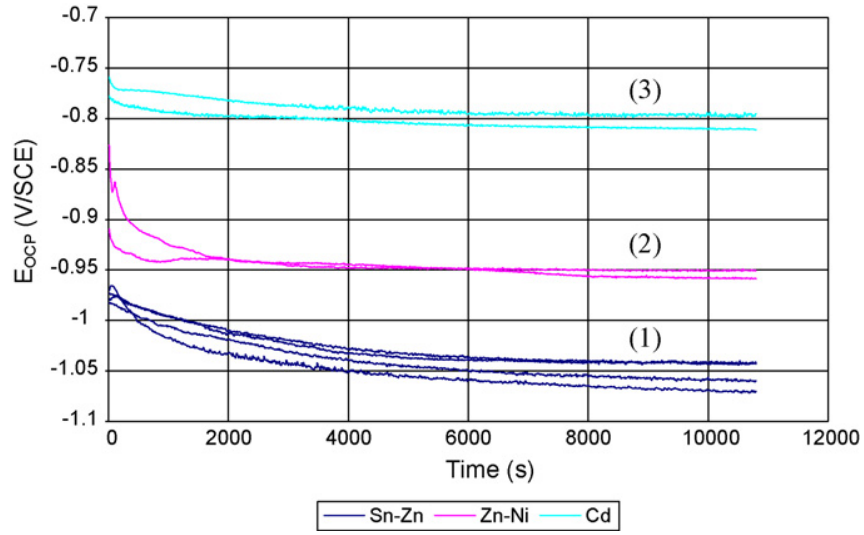

Fig. 11. $\left(E_{\mathrm{OCP}}-t\right)$ curves of tin-20 wt.\% zinc (1), zinc-12.2 wt.\% nickel (2) and cadmium (3) electrodeposited coatings in a 3 wt.\% sodium chloride solution (tin-zinc deposits 5,7,8,9 from batch B).

significant acceleration of the reduction of tin compared to that of zinc to the detriment of the hydrogen release, and consequently explain the decrease of zinc content in the deposit during the plating process.

It would be interesting within the framework of a subsequent study to deepen these two hypotheses for more important volumes of bath, even if the variations of tin and zinc concentrations in the solution, measured by XRF before and after plating, do not seem significant.

With regard to the thickness of the whole of the tin-zinc coatings, this one varies from 7 to $20 \mu \mathrm{m}$ approximately, which also confirms the results obtained previously by X-ray fluorescence spectrometry.

\subsection{Corrosion behaviour}

The study of the corrosion resistance of the elaborated deposits shows that the tin-20 wt.\% zinc alloy coating presents on the one hand a very good behaviour in chlorinated medium and on the other hand, that its corrosion resistance is comparable to, and even better than, that of the cadmium coating and superior to that of the zinc-12.2 wt.\% nickel alloy coating, in the same medium.

\subsubsection{Electrochemical measurements}

The open-circuit potential against time $\left(E_{\mathrm{OCP}}-\mathrm{t}\right)$ curves of the elaborated tin-20 wt.\% zinc deposits measured in a $3 \mathrm{wt} . \% \mathrm{NaCl}$ solution are shown in Fig. 11 as curves (1). In addition, for comparison purposes, the results of two pure cadmium deposits and of two zinc-12.2 wt.\% nickel deposits are also shown as curves (3) and (2) in Fig. 11, respectively. On curves (1), a gradual shift in the potential $\left(E_{\mathrm{OCP}}\right)$ from -0.97 to $-1.05 \mathrm{~V} / \mathrm{SCE}$ was found during the initial $8000 \mathrm{~s}$ measurement and then, an approximate constant $E_{\mathrm{OCP}}$ was obtained. This very negative $E_{\mathrm{OCP}}$ reveals that the corrosion behaviour of the tin-20 wt.\% zinc coatings is similar to that of a pure zinc coating. Thus, the corrosion behaviour of this tin-zinc alloy should be dominated by the sacrifice of zinc. This finding is similar to a previous report that zinc dissolution is the major reaction occurring at the open-circuit potential for tin-30 wt.\% zinc in $\mathrm{Na}_{2} \mathrm{SO}_{4}$ [24]. From a comparison of curves (1), the tin-20 wt.\% zinc coating also presents a similar behaviour with the zinc-12.2 wt.\% nickel coating (2), for which $E_{\mathrm{OCP}}$ decreases slightly from -0.86 to $-0.95 \mathrm{~V} / \mathrm{SCE}$ to stabilize at the end of a time approaching $8000 \mathrm{~s}$, and with pure cadmium (3), for which $E_{\mathrm{OCP}}$ decreases very slowly from -0.77 to $-0.81 \mathrm{~V} / \mathrm{SCE}$ during the initial $6000 \mathrm{~s}$ measurement before stabilization. Interestingly, these results reveal that corrosion behaviour of tin-20 wt.\% zinc is very similar to that of pure 
cadmium deposit although the presence of active zinc significantly shifts its $E_{\mathrm{OCP}}$ negatively. Moreover, these results enable the verification of the sacrificial character of the tin-20 wt.\% zinc coating on steel, which $E_{\mathrm{OCP}}$ is effectively lower than the $E_{\mathrm{OCP}}$ of iron $(-0.70 \mathrm{~V} / \mathrm{SCE})$, measured in the same $3 \mathrm{wt}$.\% sodium chloride solution. Tin-zinc ensures probably the most effective active protection, compared with cadmium and zinc-nickel, because it has with steel the most important electromotive force (emf).

Fig. 12a shows the linear polarization resistance against time $\left(R_{\mathrm{p}}-t\right)$ curves of the elaborated tin-20wt.\% zinc deposits, of two pure cadmium deposits and of two zinc-12.2 wt.\% nickel deposits, measured in a $3 \mathrm{wt} . \% \mathrm{NaCl}$ solution, as curves (1), (3) and (2), respectively. The measured resistance being inversely related to the corrosion rate, Fig. 12b shows the evolution of the corrosion rate against time $\left(1 / R_{\mathrm{p}}-t\right)$ curves of all these coatings. It is however necessary to note that $R_{\mathrm{p}}$ generally leads to estimate rates slower than they are.

The polarization resistance of the tin-zinc coatings increases as a first step very strongly from 0.8 to $2.8 \mathrm{k} \Omega \mathrm{cm}^{2}$ average and then tends to stabilize after $8000 \mathrm{~s}$. Tin-zinc therefore resists corrosion in the presence of chlorides. The cadmium deposits are quite close in behaviour, even if the evolution of $R_{\mathrm{p}}$ is less pronounced: $R_{\mathrm{p}}$ increases slowly from 0.3 to $0.8 \mathrm{k} \Omega \mathrm{cm}^{2}$. Regarding the zinc-nickel, it presents the worst behaviour in that solution, its surface remaining apparently stable or even degrading slowly throughout the test. Its resistance decreases progressively from 1.1 to $0.9 \mathrm{k} \Omega \mathrm{cm}^{2}$.

Tin-zinc deposit, corroding slightly during the first $2 \mathrm{~h}$ of immersion, probably forms on surface a more and more passive layer of corrosion products. This complex layer, certainly consisting of very stable oxides and hydroxides of zinc, but also chloride, oxichloride and hydroxichloride of zinc, allows, by limiting the dissolution of the alloy, for a significant lowering in its corrosion
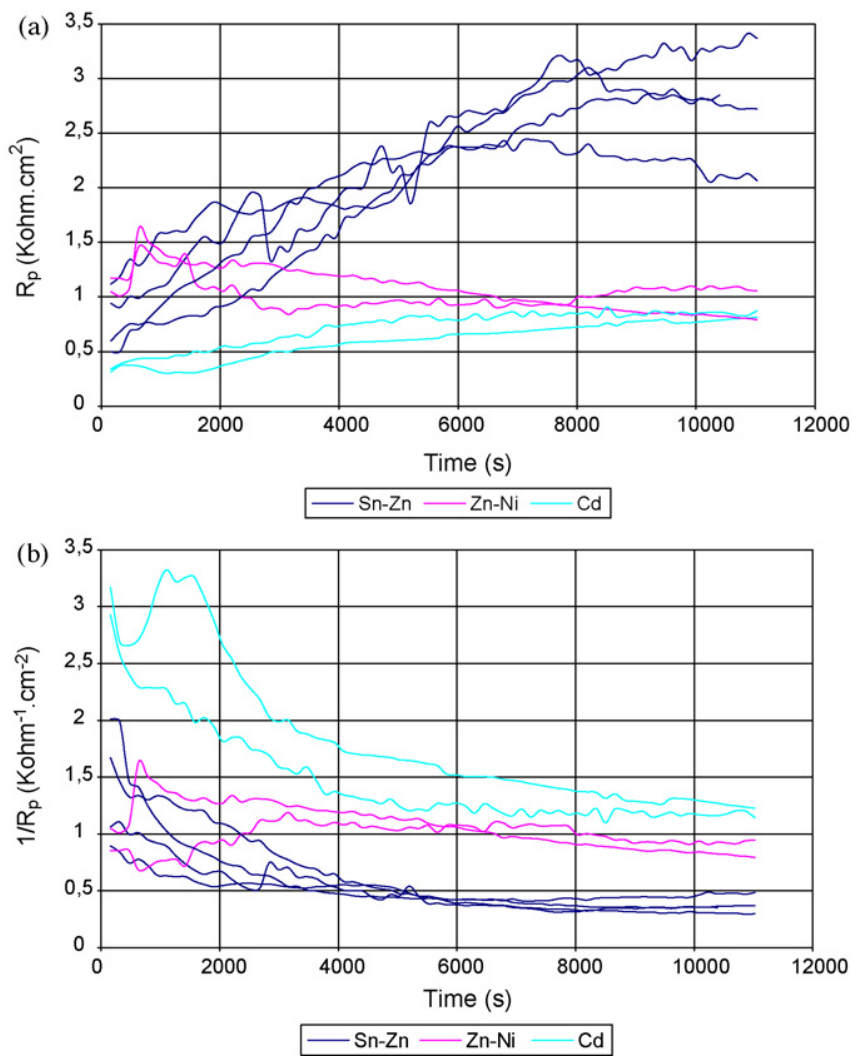

Fig. 12. $\left(R_{\mathrm{P}}-t\right)(\mathrm{a})$ and $\left(1 / R_{\mathrm{p}}-t\right)$ (b) curves of tin-20 wt.\% zinc (1), zinc-12.2 wt.\% nickel (2) and cadmium ( 3 ) electrodeposited coatings in a $3 \mathrm{wt} . \%$ sodium chloride solution (tin-zinc deposits 5,7,8,9 from batch B).

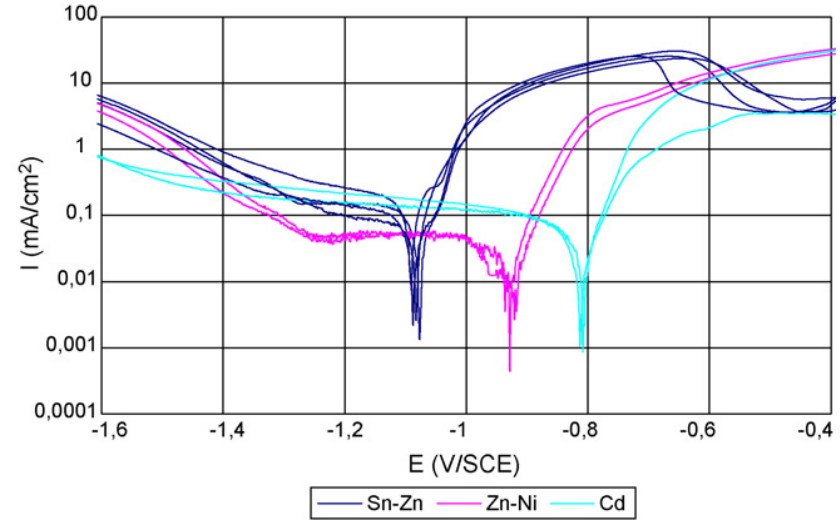

Fig. 13. Polarization curves of tin-20 wt.\% zinc (1), zinc-12.2 wt.\% nickel (2) and cadmium (3) electrodeposited coatings in a $3 \mathrm{wt}$.\% sodium chloride solution (tin-zinc deposits $5,7,8,9$ from batch $B$ ).

rate (Fig. 12b). Regarding the cadmium deposit, its corrosion rate, fast enough to start, probably leads to a sufficient deterioration of the surface coating to ensure a good protection, which reflects the decrease of the corrosion rate. Zinc-nickel deposit presents a relatively similar behaviour to cadmium, although the corrosion rate of the cadmium is slightly superior in the first moments. The tin-20 wt.\% zinc coating, compared with pure cadmium and zinc-12.2 wt.\% nickel alloy coatings, has the lowest corrosion rate in that chlorinated medium.

Fig. 13 shows the polarization curves of the elaborated tin-20 wt.\% zinc deposits, of two pure cadmium deposits and of two zinc-12.2 wt.\% nickel deposits, measured in a $3 \mathrm{wt} . \% \mathrm{NaCl}$ solution, as curves (1), (3) and (2), respectively. Apart from the fact that their respective potentials are different, $-1.08 \mathrm{~V} / \mathrm{SCE}$ for tin-zinc, $-0.93 \mathrm{~V} / \mathrm{SCE}$ for zinc-nickel and $-0.80 \mathrm{~V} / \mathrm{SCE}$ for cadmium, which confirms the preceding results, all tested deposits have appreciably the same behaviour. Indeed, the average corrosion current is only of $0.040 \mathrm{~mA} \mathrm{~cm}^{-2}$ for all the tin-zinc deposits, also of $0.040 \mathrm{~mA} \mathrm{~cm}^{-2}$ for zinc-nickel deposits and of $0.037 \mathrm{~mA} \mathrm{~cm}^{-2}$ for cadmium deposits.

By considering that these coatings are all corroded according to a mode of uniform corrosion, it is possible to estimate their corrosion rates. After calculation, tin-zinc and zinc-nickel deposits have the same corrosion rate of $0.58 \mathrm{~mm}_{\text {year }}{ }^{-1}$. Given the aggressiveness of the environment, this relatively low rate is clearly lower than that of the cadmium coating, for which the loss of thickness would be of $0.78 \mathrm{~mm}_{\text {year }}{ }^{-1}$.

However, these results should be considered with caution. Additional tests of the composition of the deposits, made by X-ray fluorescence spectrometry, tend to show that corrosion of tin-zinc coatings does not develop according to a mode of generalized corrosion, but rather according to a mode of selective corrosion with preferential dissolution of the zinc. The mass content of zinc in the coating, measured after corrosion tests, is almost zero while the tin content approaches $100 \%$.

Impedance measurements of electrochemical interfaces are applied to many sectors, including the study of corrosion. As part of this work, impedance measurements were recorded at OCP in a 3 wt.\% $\mathrm{NaCl}$ solution. Fig. 14 shows Nyquist plots of the elaborated tin-20 wt.\% zinc deposits, of two pure cadmium deposits and of two zinc-12.2 wt.\% nickel deposits, as curves (1), (3) and (2), respectively. As during the previous trials, the behaviour of the tin-zinc coatings is reproducible from one test to the other one, as that of zinc-nickel and cadmium coatings. Besides, tin-zinc and zinc-nickel present the same behaviour, slightly different from that of the cadmium. 


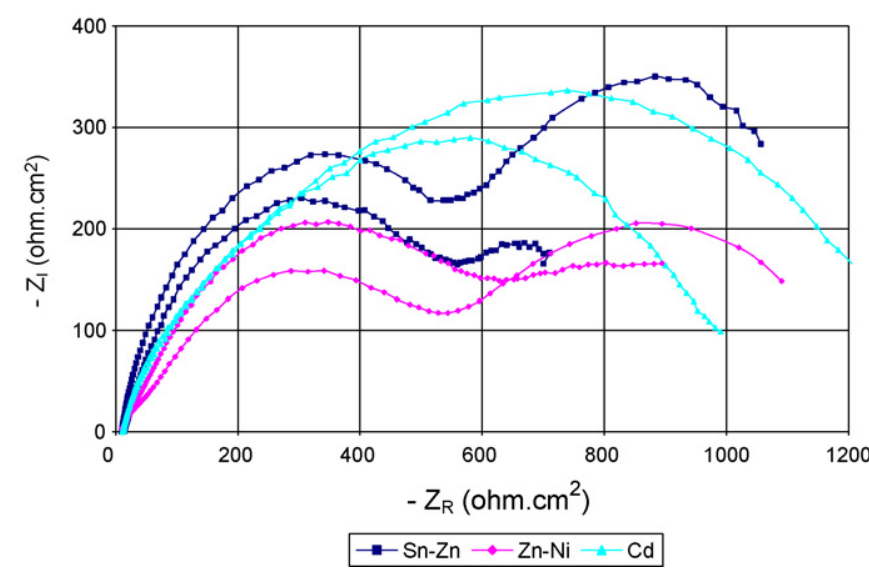

Fig. 14. EIS measurements of tin-20 wt.\% zinc (1), zinc-12.2 wt.\% nickel (2) and cadmium (3) electrodeposited coatings in a $3 \mathrm{wt}$.\% sodium chloride solution (tin-zinc deposits 5,7,8,9 from batch B).

Nyquist diagrams of tin-zinc deposits show two capacitive loops. The intersection (direct or extrapolated) of these two loops with the real axis allows us, in the first approximation, to estimate the resistance of the sodium chloride solution $R_{\mathrm{s}}$, of the transfer resistance $R_{\mathrm{t}}$ and of the polarization resistance $R_{\mathrm{p}}$, respectively equal to 12,600 and $1200 \Omega \mathrm{cm}^{2}$. The first loop, obtained for high frequencies, corresponds to the double layer capacitance: the coating behaves then as a RC circuit, equivalent to the potential difference at the metal-solution interface of an immersed metallic electrode. The second loop, obtained for low frequencies, reveals the formation of a passive film for which $R_{\mathrm{p}}$ is superior to $R_{\mathrm{t}}$. It is then possible to believe that a charge transfer occurred without mass transport by dissolution of the coating. This could be interpreted by a preferential dissolution of zinc according to a mode of selective corrosion of the tin-zinc alloy deposit.

The behaviour at the open-circuit potential of the tin-zinc coating is very close to the behaviour of the zinc-nickel coating in the same environment. Only $R_{\mathrm{t}}$ and $R_{\mathrm{p}}$ are slightly different. On the other hand, compared with cadmium, the tin-zinc deposit presents a very different behaviour (Fig. 14). Nyquist diagrams of cadmium deposits do not effectively show a second capacitive loop: these diagrams correspond to the diagram of a metallic electrode immersed in solution. Corrosion of the cadmium coating in the presence of chloride is a relatively slow corrosion generalized on every surface in touch with the solution.

\subsubsection{Salt spray test}

The test was conducted according to ASTM B117 on four tin-20 wt.\% zinc coatings referenced A1, B1, D1 and E1, of a thickness of $10,9,7$ and $8 \mu \mathrm{m}$, respectively, two zinc-12.2 wt.\% nickel coatings of a thickness of $8 \mu \mathrm{m}$ and two cadmium coatings of a thickness of $10 \mu \mathrm{m}$, all electrodeposited on steel plates. Fig. 15 allows for the observation of the initial state of the surface of the deposits before the beginning of the test. After $24 \mathrm{~h}$, a first visual inspection allowed us to notice the appearance of white rust on almost the whole surface of the tin-zinc and zinc-nickel coatings. After $216 \mathrm{~h}$ of exposure to salt spray, the first traces of red rust appeared on the surface of two of the four tin-zinc deposits (D1 and E1) of a thickness of 7 and $8 \mu \mathrm{m}$, respectively and on the surface of both zinc-nickel deposits of a thickness of $8 \mu \mathrm{m}$. We were also able to observe the appearance, however small, of several traces of white rust on the surface of both cadmium deposits of a thickness
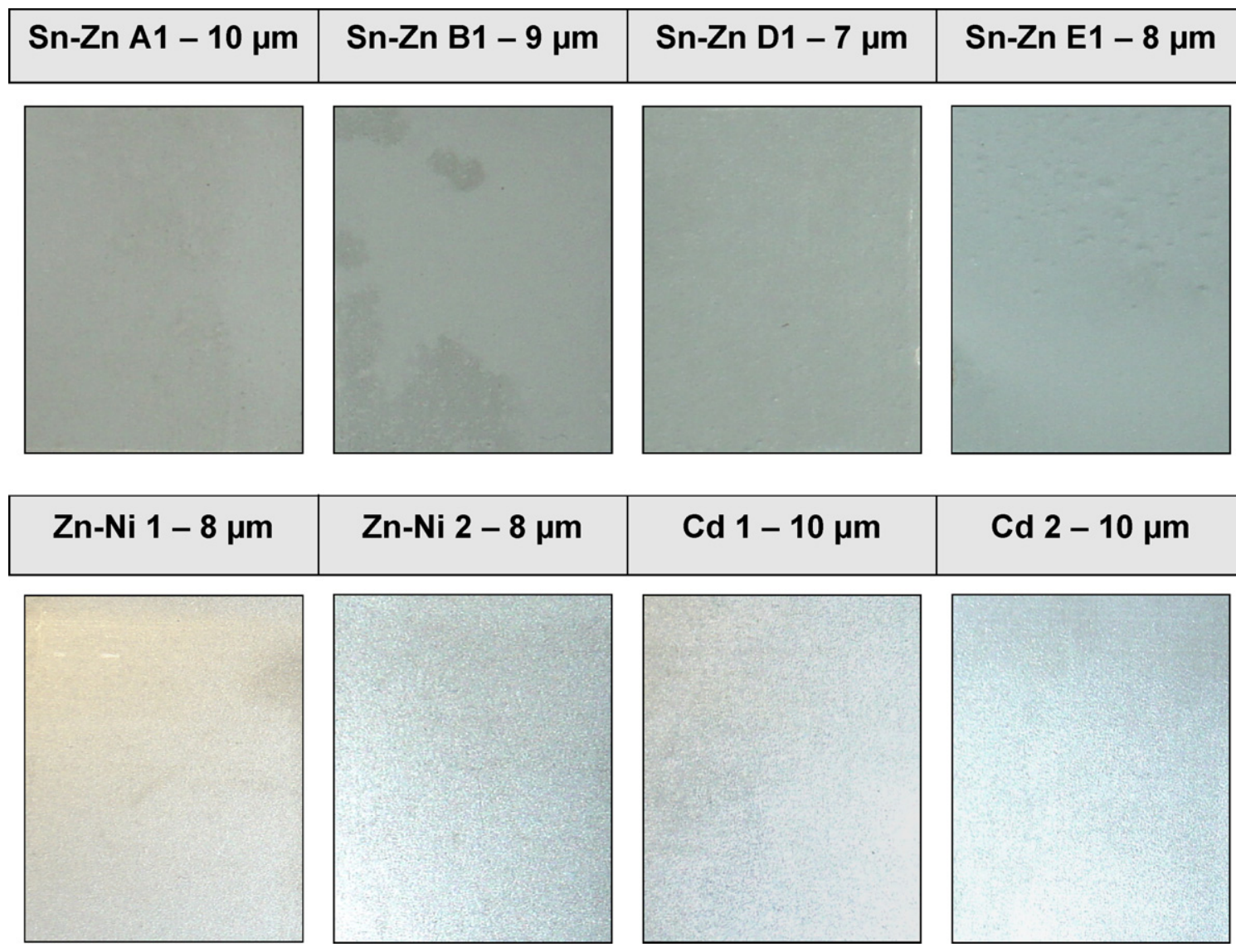

Fig. 15. Photograph of the coatings before salt spray test (ASTM B117) (dimensions of the plates: $70 \mathrm{~mm} \times 40 \mathrm{~mm}$ ) 


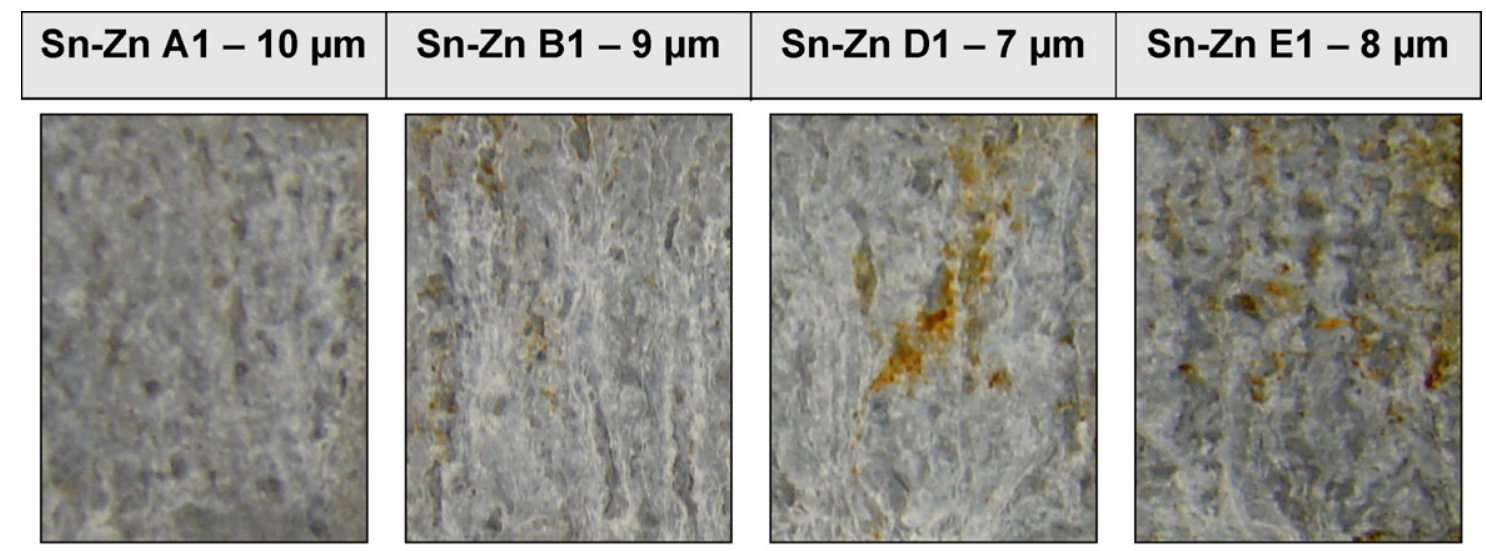

\begin{tabular}{|l|l|l|l|}
\hline Zn-Ni 1-8 $\mu \mathrm{m}$ & Zn-Ni 2-8 $\mu \mathrm{m}$ & Cd 1-10 $\mu \mathrm{m}$ & $\mathrm{Cd} 2-10 \mu \mathrm{m}$ \\
\hline
\end{tabular}
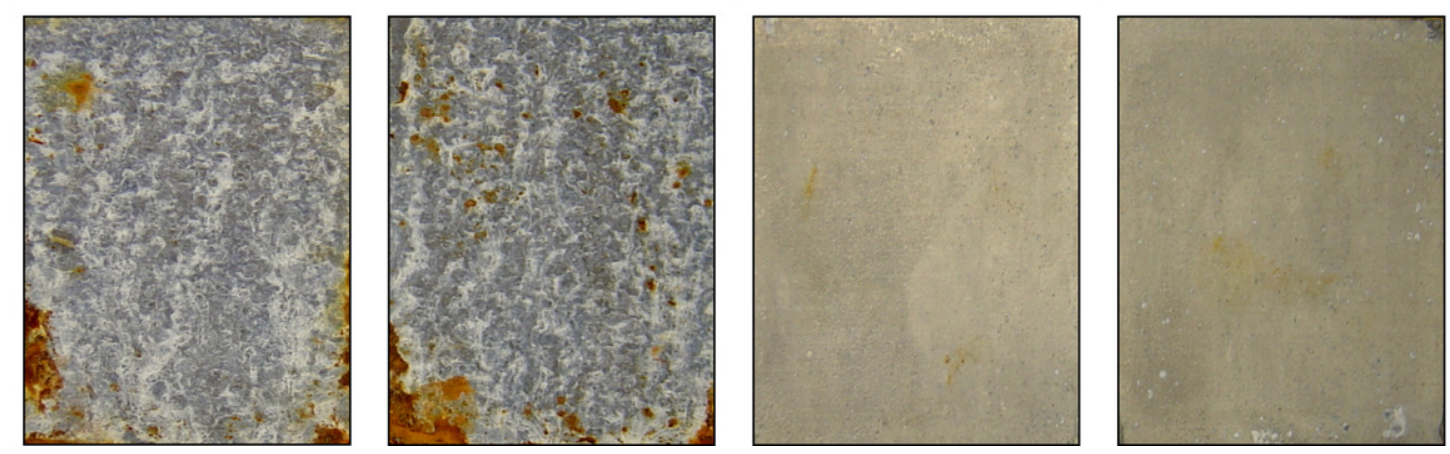

Fig. 16. Photograph of the coatings exposed to salt spray test (ASTM B117) after $408 \mathrm{~h}$ (dimensions of the plates: $70 \mathrm{~mm} \times 40 \mathrm{~mm}$ ).

of $10 \mu \mathrm{m}$. Afterwards corrosion progressed slowly without really significant evolution. After $312 \mathrm{~h}$ of exposure, the first traces of red rust, however light, appeared on the surface of the third tin-zinc coating (B1) of a thickness of $9 \mu \mathrm{m}$. Finally after $408 \mathrm{~h}$ of exposure, the first traces of red rust appeared on the surface of the cadmium deposits of a thickness of $10 \mu \mathrm{m}$. Fig. 16 shows the final state of the tested coatings. It is especially very interesting to note that the tin-zinc deposit referenced A1 still presented no trace of red rust.

An electrolytic tin-20 wt.\% zinc coating of a thickness of $10 \mu \mathrm{m}$ is consequently more effective than a cadmium coating of same thickness within the framework of the salt spray test defined by the standard ASTM B117.

\subsection{Friction resistance}

Fig. 17 shows the sliding friction profiles of one elaborated tin-20wt.\% zinc deposit, of one cadmium deposit and of one zinc-12.2 wt.\% nickel deposit. The tin-zinc coating behaves relatively well. The measured couple, after a short-lived of grinding, does not effectively possess a high value; the total jamming, obtained after complete wear of the coating, appears only after a relatively long period, contrary to the almost immediate jamming observed in the case of the zinc-nickel coating. As regards to the cadmium deposit, its behaviour is very good: on one hand the value of the developed friction couple is slightly lower than that of the couple of the tin-zinc coating; on the other hand, the total jam-
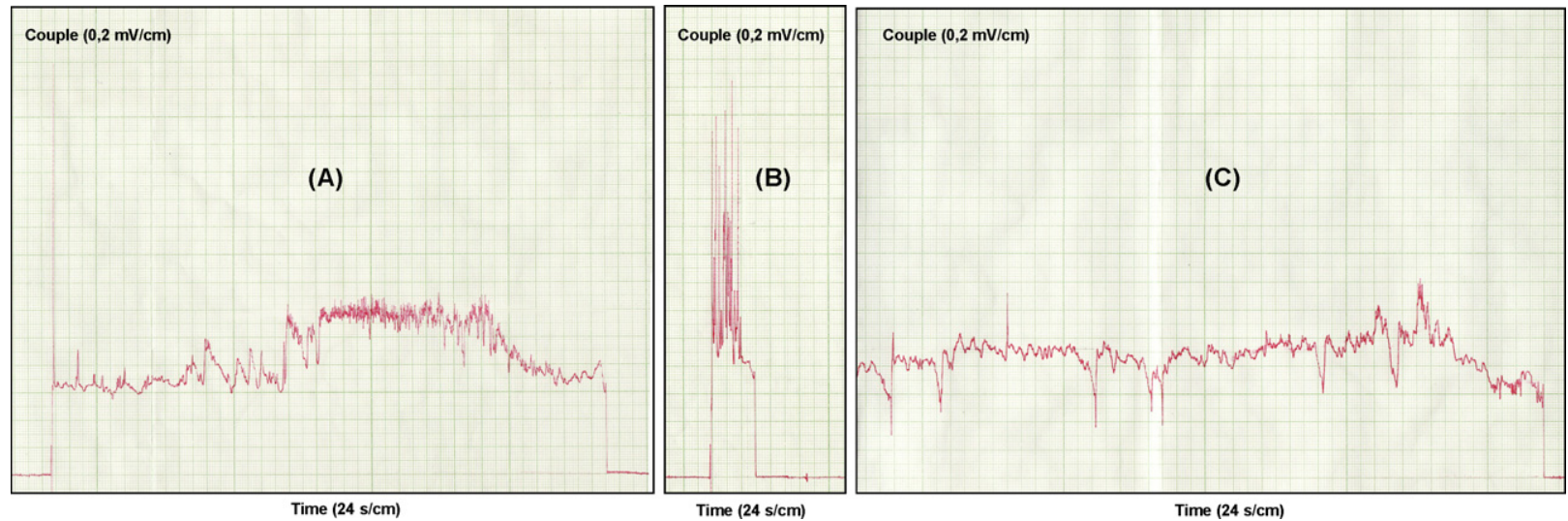

Fig. 17. Sliding friction profiles of one elaborated tin-20 wt.\% zinc deposit (a), of one cadmium deposit (b) and of one zinc-12.2 wt.\% nickel deposit (c). 
ming appears only after a very important period. The wear of the deposit during the friction probably allows to lubricate the contact between the cadmium coating and the steel track.

The friction coefficient values measured, respectively $0.14,0.20$ and 0.11 for the tin-zinc, the zinc-nickel and the cadmium coatings, confirm the previous observations.

\section{Conclusion}

According to the bibliography, it is difficult to find a replacement coating for cadmium. And although some candidates, such as zinc-nickel coating, are entitled to fill some of its functions, no coating covers all its properties. Within the framework of this study, the results show that the electroplated tin- $20 \mathrm{wt} . \%$ zinc alloy coating, produced from non-cyanide bath Zincrolyte ${ }^{\mathrm{TM}}$ Sn 0406, offers several possibilities including excellent corrosion performance.

The tin-20 wt.\% zinc coating has an electrochemical corrosion potential of $-1 \mathrm{~V} / \mathrm{SCE}$, thus enabling it to provide a very efficient electrochemical protection of steel. The results of the corrosion tests performed confirm this behaviour.

The tin-20 wt.\% zinc coating provides superior corrosion protection when compared to zinc-12.2 wt.\% nickel and cadmium coatings, requiring considerably longer time ( $408 \mathrm{~h}$ for a thickness of $10 \mu \mathrm{m}$ ) to develop red rust in a salt spray environment.

Although slightly higher than the friction coefficient of the cadmium coating, the friction coefficient of the tin-zinc coating is relatively low. This minor difference does not reduce the capability of the tin-zinc coating to replace the cadmium deposit.

In addition, the electroplating process developed and optimized further to Hull cell tests is perfectly reproducible for well-defined parameters: cathodic current density included between 1.5 and $2 \mathrm{Adm}^{-2}$, with $\mathrm{pH}$ equal to 11.0 and the temperature of the bath at $70^{\circ} \mathrm{C}$. The different analyses, by scanning electron microscopy and glow discharge optical emission spectrometry in particular, allowed us to confirm the reproducibility of the process and to control the stability of the bath. All the deposits have the same relatively uniform morphology, which consists of nodules from approximately $4 \mu \mathrm{m}$ diameter. The referred composition, $80 \%$ tin for $20 \%$ zinc, which provides the best corrosion resistance, is also perfectly reproducible.

The results obtained in this study being very promising, we have decided to pursue our investigations. We plan to examine the crosssection of the coatings by scanning electron microscopy (SEM) and study the adhesion on the substrate; we will also analyse the produced deposits by X-ray diffraction (XRD) to identify the crystalline phases present in the alloy and the preferred orientations present in these phases. These results, which will be the subject of a forthcoming article, would allow us to add precision on the corrosion behaviour of the tin-20 wt.\% zinc coatings.

Finally, some properties such as abrasion resistance or compatibility of tin-zinc with some aluminium alloys, very used in aerospace applications, deserve to be studied.

\section{References}

[1] S.J. Bluden, Adv. Mater. Processes 137 (1991) 37

[2] E. Budman, M. McCoy, Trans. Inst. Met. Finish. 9 (1995) 10.

[3] E. Budman, D. Stevens, Trans. Inst. Met. Finish. 76 (1998) B34.

[4] P.J. Miller, J.W. Cuthberson, Met. Finish. J. 47 (1949) 44.

[5] F.A. Lowenheim, R.M. MacIntosh, J. Electrodep. Tech. Soc. 27 (1951) 115

[6] D.A. Schario, M.L. Klingenberg, E.W. Brooman, Abstracts of the 190th Meeting of the Electrochemical Society, vol. 96-2, no. 309, The Electrochemical Society, Pennington, NY, 1996, p. 398.

[7] M. Pushpavanaman, Bull. Electrochem. 16 (2000) 559.

[8] E. Popesco, R. Tournier, Le zingage électrolytique pratique, Medro Edition, 1999

[9] P. Marino, British Patent 10,133 (1915).

[10] M.M. Thompson, J.C. Patten, U.S. Patent 1,876 (1932), p. 156.

[11] B.R. Haueisen, U.S. Patent 1,904 (1930), p. 732.

[12] Mead Research Engineering Co., British Patent 407,670 (1931).

[13] S.O. Cowper-Cole, Ferbrite Ltd., British Patent 420,103 (1933).

[14] V.A. Lowinger, S.W. Baier, British Patent 533,610 (1939).

[15] R.M. Angles, J. Electrdep. Tech. Soc. 21 (1946) 268.

[16] J.W. Cuthbertson, R.M. Angles, J. Electrochem. Soc. 94 (1948) 73.

[17] F.A. Lowenheim, U.S. Patent 2,675 (1954), p. 347.

[18] A.E. Davis, R.M. Angles, J.W. Cuthbertson, Trans. Inst. Met. Finish. 29 (1953) 227

[19] N. Dohi, K. Obata, J. Met. Finish. Soc. Jpn. 24 (1973) 674.

[20] O.A. Ashiru, J. Shirokoff, Appl. Surf. Sci. 103 (1996) 159.

[21] St. Vitkova, V. Ivanova, G. Raichevsky, Surf. Coat. Technol. 82 (1996) 226

[22] M. An, Y. Zhang, J. Zhang, Z. Yang, Z. Tu, Plating Surf. Finish. 86 (1999) 927.

[23] S.M. Abdel-Wahab, E. Mohamed, S.M. Rashwan, Metallurgy 54 (2000) 268

[24] K. Wang, H.W. Pickering, K.G. Weill, Electrochem. Acta 46 (2001) 3835.

[25] E. Guaus, J. Torrent-Burgues, J. Electroanal. Chem. 549 (2003) 25.

[26] E. Guaus, J. Torrent-Burgues, J. Electroanal. Chem. 575 (2005) 301.

[27] S. Dubent, M. De Petris-Wery, M. Saurat, H.F. Ayedi, Mater. Chem. Phys. 104 (2007) 146.

[28] R.M. Angles, R. Kerr, Engineering 161 (1946) 289.

[29] W.H. Ailor, Atmospheric Corrosion, J. Wiley, New York, 1982.

[30] V.Q. Kinh, Les alliages électrodéposés, I. Élaboration et propriétés, Corrosion T.P.F. 19 , no. 3, 1971 , p. 102.

[31] R.M. Angles, F.V. Jones, J.W. Price, J.W. Cuthberson, J. Electrdep. Tech. Soc. 21 (1946) 19.

[32] R. Payling, D. Jones, A. Bengtson, Glow Discharge Optical Emission Spectrometry, J. Wiley \& Sons, Chichester, 1997.

[33] T. Nelis, R. Payling, Glow Discharge Optical Emission Spectroscopy: A Practical Guide, RSC Analytical Spectroscopy Monographs, Cambridge, 2003.

[34] K. Marcus, Glow Discharge Spectroscopies, Plenum Publishing Corporation, 1993.

[35] K.-L. Lin, T.-P. Liu, Mater. Chem. Phys. 56 (1998) 171.

[36] B. Veeraraghavan, B. Haran, S.P. Kumaraguru, B.N. Popov, J. Electrochem. Soc. 150 (2003) B131.

[37] C.-C. Hu, C.-K. Wang, Electrochem. Acta 51 (2006) 3692

[38] R. Solmaz, G. Kardas, Energy Convers. Manage. 48 (2007) 583. 